International Journal of Advanced Research in Electrical, Electronics and Instrumentation Engineering

(An ISO 3297: 2007 Certified Organization)

Vol. 3, I ssue 11, November 2014

\title{
Harmonic Analysis of Three Phase SPWM and SVPWM Converters
}

\author{
Kavita Nagar ${ }^{1}$, Ashok Kumar Sharma ${ }^{2}$, Dr. D.K. Palwalia ${ }^{3}$, Amit Sharma ${ }^{4}$ \\ M.Tech. Student, Dept. of EE, University College of Engineering, RTU, Kota, Rajasthan, India ${ }^{1}$ \\ Associate Professor, Dept. of EE, University College of Engineering, RTU, Kota, Rajasthan, India ${ }^{2}$ \\ Associate Professor, Dept. of EE, University College of Engineering, RTU, Kota, Rajasthan, India ${ }^{3}$ \\ M.Tech. Student, Dept. of EE, University College of Engineering, RTU, Kota, Rajasthan, India ${ }^{4}$
}

\begin{abstract}
Pulse width modulation (PWM) converters are frequently used due to unity power factor operation with reduced total harmonic distortion (THD) at ac mains and also provide constant-regulated dc output voltage even under fluctuations of ac voltage and dc load. This paper contains the harmonics analysis of sinusoidal PWM (SPWM) technique and space vector PWM (SVPWM) technique for three-phase AC to DC converters using MATLAB/SIMULINK software. In this paper simulation models for both techniques are simulated with closed loop at rated load condition and harmonics analysis has been done using FFT tool of simulink in MATLAB. The performance of SVPWM and SPWM technique are analysed for harmonics present in input current with power factor. SVPWM is the efficient technique because of the better performance.
\end{abstract}

KEYWORDS: Pulse width modulation, sinusoidal PWM, space vector PWM, unity power factor, THD, MATLAB.

\section{I.INTRODUCTION}

The AC/DC power converters are extensively used in various applications like household electric appliances, power conversion, dc motor drives, adjustable-speed ac drives, HVDC transmission, power supplies like SMPS and UPS and so on. The main problems faced by the power electronic design engineers are about the reduction of harmonic content in low or medium power applications. Normally the input voltage to an AC-to-DC converter is sinusoidal but the input current is non-sinusoidal i.e. harmonic currents are present in the ac lines. Harmonics have a negative effect on the operation of the electrical system and therefore, an increasing attention is paid to their generation and control. Harmonics have a negative effect on the power factor as well. The addition of harmonic currents to the fundamental component increases the total rms current hence harmonics will affect the power factor of the circuit. Unity power factor, lower harmonic current or low input current THD and fixed DC output voltage with minimum ripple are the important parameters in rectifier. A pulse width modulation (PWM) rectifier serves all these purposes, which operates in four quadrants with high power factor. The PWM is a very advance and useful technique in which width of the gate pulses are controlled by various mechanisms. PWM rectifiers shift the frequency of the dominant harmonics to a higher value, so that they can be easily filter harmonics by employing a small passive filter [1]-[8]. The PWM rectifier is also known as active front end (AFE) converter. By using advance PWM control techniques such as sinusoidal PWM (SPWM) and space vector PWM (SVPWM), the input current can be made nearly sinusoidal with minimum total harmonic distortion (THD) and unity power factor operation can also be achieved. Space vector modulation utilizes dc bus voltage more efficiently and generates less harmonic distortion in a three phase voltage source rectifier. SVPWM technique is an advanced and possibly the best PWM technique for variable speed drive applications [9]. In this paper MATLAB model of both techniques are simulated at rated load condition and then comparative harmonic analysis in terms of input current THD and input power factor has been done.

\section{II.SINUSOIDAL PULSE WIDTH MODULATION (SPWM)}

In sine-triangle PWM, three phase sinusoidal reference modulating signals are compared against a common triangular carrier to generate PWM switching gate triggering pulses for the three phases. The rectifier switching frequency is governed by the frequency of the triangular waveform and this carrier frequency is very high compared to the 


\title{
International Journal of Advanced Research in Electrical, Electronics and Instrumentation Engineering
}

\author{
(An ISO 3297: 2007 Certified Organization)
}

\section{Vol. 3, I ssue 11, November 2014}

frequency of modulating signal. The frequency of reference signal controls the modulation index $\mathrm{m}$, rms voltage $\mathrm{V}_{\mathrm{rms}}$ and output voltage $\mathrm{V}_{\mathrm{o}}$. The number of pulses per half cycle depends on carrier frequency. The triangle waveform frequency or switching frequency controls the speed at which the switches are turned off and on. The magnitude and frequencies of the fundamental component in the line side are controlled by changing the magnitude and frequency of the modulating signal. It is simple and linear between $0 \%$ and $78.5 \%$ of six step voltage values, which results in poor voltage utilization [10]-[13]. The block diagram of sinusoidal PWM converters has shown in fig 1. Generally, the control structure of a three-phase six-switch PWM boost converter consists of double close loop with an inner current control loop and an outer voltage control loop. The line inductors provide energy storage and allow the rectifier to operate in a boost configuration.

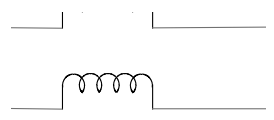

Fig .1 Block diagram of three-phase sinusoidal PWM boost rectifier

The switching pulses are generated by current mode control scheme which is shown in fig 2. A current-mode control scheme is required for the line currents. The DC bus voltage is controlled by comparing of measured DC voltage to the reference DC voltage. This error signal is passed through a PI controller which then forms the current amplitude reference required for all three inner current control loops. The current controller senses the input current and compares it with sinusoidal reference currents. The current amplitude reference is multiplied by three sinusoidal templates each with a $120^{\circ}$ phase apart to form the true current references.

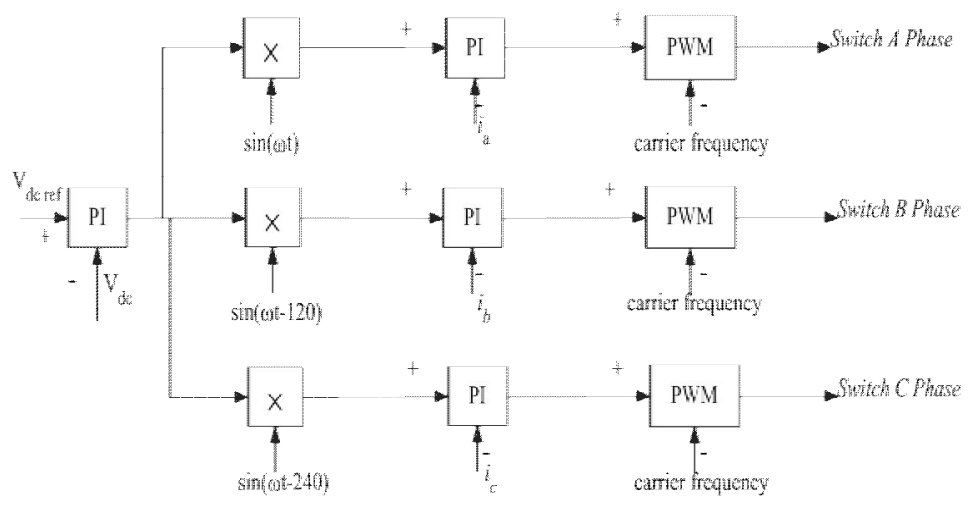

Fig .2 Control circuit of current mode control scheme for SPWM rectifier

For unity power factor operation it is required that each sinusoidal reference is in phase with the respective supply phase voltage. The inductor current is measured and compared to a reference signal. The error is passed through a proportional and integral (PI) controller providing high gain at low frequencies, but having a filtering effect on the high-frequency ripple current. The constants of the PI controllers are set by hit and trial method to produce a stable system with good response. Now, this signal is compared to a triangular carrier wave to generate the required PWM 


\title{
International Journal of Advanced Research in Electrical, Electronics and Instrumentation Engineering
}

\author{
(An ISO 3297: 2007 Certified Organization)
}

\section{Vol. 3, I ssue 11, November 2014}

signal to control the switches. This technique has excellent features, like real-time control and easily obtained drive signals. Merits are simple to implement, easy to control etc. Demerits are dc link voltage ripple introduces additional output ripple, high THD, low input power factor at low and medium power applications.

\section{III.SPACE VECTOR PULSE WIDTH MODULATION}

A different approach to PWM modulation is based on the space vector representation of voltage in the $\alpha-\beta$ plane. In SVPWM, the voltage reference is provided using a revolving reference vector and magnitude and frequency of the fundamental component in the line side are controlled by the magnitude and frequency of the reference voltage vector respectively. The space vector modulation (SVM) technique is an advanced, computation intensive digital PWM technique in which the objective is to generate PWM load line voltages that are on average equal to given load line voltages. This is done in each sampling period by properly selecting the switch states from the valid ones of VSR and by proper calculation of the period of times they are used. It is a more sophisticated technique for generating sine wave that provides a higher voltage to the motor with lower THD [10]-[14].

The block diagram of SVPWM rectifier has shown in the fig 3. This block diagram has three main blocks, stationary coordinate's estimator, SVM signal generator and switching table. From the ac side three-phase currents ( $\left.i_{a}, i_{b}, i_{c}\right)$ converted to two-phase current ordinates $\left(i_{\alpha} \& i_{\beta}\right)$. Similarly, from the three-phase voltage converted to two-phase voltage ordinates and cosine values by using Clark's transformation. The current coordinate are changed to voltage cosines. The controller consists of outer bus voltage regulation loop and inner phase current regulation loop. Actual bus feedback $\left(V_{d c}\right)$ is compared with the desired bus voltage $\left(V_{d c}\right.$ ref $)$ and the error $\left(\right.$ delta $\left.V=V_{d c r e f}-V_{d c}\right)$ is passed through a PI controller, the outer loop generates the amplitude of the reference current $\left(\mathrm{I}_{\mathrm{m}}\right)$. The stationary co-ordinates estimator block has two inputs (input supply and line current $\mathrm{I}_{\mathrm{m}}$ ). The input current voltage vector coordinates is compare to input voltage $\mathrm{d}-\mathrm{q}$ coordinates and add with inductance drop. These $\mathrm{d}-\mathrm{q}$ voltage vectors have converted to $\alpha-\beta$ coordinates. The stationary estimator estimates $V_{\alpha}$ and $V_{\beta}$. In SVM block, number of the instantaneous sector and the time $T_{1}, T_{2}$ and $T_{0}$ are getting from the stationary coordinates $V_{\alpha}$ and $V_{\beta}$. The number of sector $\left(S_{n}\right)$ and the required switching time $\left(\mathrm{T}_{\mathrm{n}}\right)$ select instantaneous firing signal from the switching table [15].

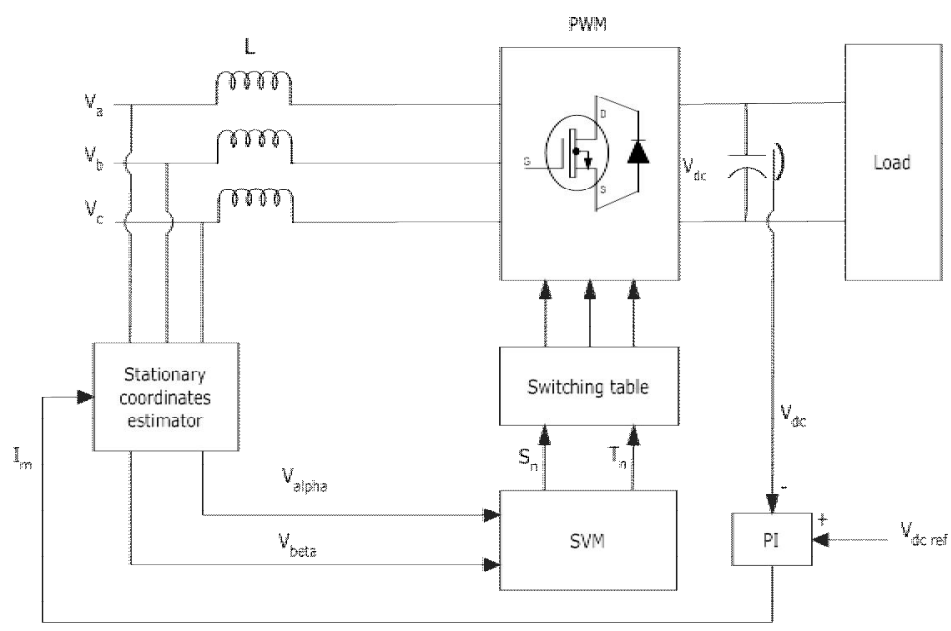

Fig .3 Block diagram of space vector modulation rectifier [15]

(a) Space Vector or 2-phase Representation of the Three-Phase Quantity [14], [16]:

$\mathrm{V}^{*}=\mathrm{V}_{\alpha}+\mathrm{j}_{\beta}=\frac{2}{3}\left(\mathrm{~V}_{a}+\mathrm{aV}_{\mathrm{b}}+\mathrm{a}^{2} \mathrm{~V}_{\mathrm{c}}\right)$

Where, $\mathrm{a}=\mathrm{e}^{\mathrm{j} 2 \pi / 3}$ 


\section{International Journal of Advanced Research in Electrical, Electronics and Instrumentation Engineering}

(An ISO 3297: 2007 Certified Organization)

\section{Vol. 3, I ssue 11, November 2014}

$$
\begin{aligned}
& |\mathrm{V}|=\sqrt{\mathrm{V}_{\alpha}{ }^{2}+\mathrm{V}_{\beta}{ }^{2}}, \tan \alpha=\frac{\mathrm{V}_{\beta}}{\mathrm{V}_{\alpha}} \\
& \mathrm{V}_{\alpha}+\mathrm{j}_{\beta}=2 / 3\left(\mathrm{~V}_{\mathrm{a}}+\mathrm{e}^{\mathrm{j} 2 \pi / 3} \mathrm{~V}_{\mathrm{b}}+\mathrm{e}^{-\mathrm{j} 2 \pi / 3} \mathrm{~V}_{\mathrm{c}}\right) \\
& =2 / 3\left[\mathrm{~V}_{\mathrm{a}}+(\cos 2 \pi / 3) \mathrm{V}_{\mathrm{b}}+(\cos 2 \pi / 3) \mathrm{V}_{\mathrm{c}}\right]+\mathrm{j} 2 / 3\left[(\sin 2 \pi / 3) \mathrm{V}_{\mathrm{b}}-(\sin 2 \pi / 3) \mathrm{V}_{\mathrm{c}}\right]
\end{aligned}
$$

Equating real and imaginary parts:

$$
\begin{aligned}
& \left(\begin{array}{c}
\mathrm{V}_{\alpha} \\
\mathrm{V}_{\beta}
\end{array}\right)=2 / 3\left(\begin{array}{ccc}
1 & \cos 2 \pi / 3 & \cos 2 \pi / 3 \\
0 & \sin 2 \pi / 3 & -\sin 2 \pi / 3
\end{array}\right)\left(\begin{array}{c}
\mathrm{V}_{\mathrm{a}} \\
\mathrm{V}_{\mathrm{b}} \\
\mathrm{V}_{\mathrm{c}}
\end{array}\right) \\
& \left(\begin{array}{c}
\mathrm{V}_{\alpha} \\
\mathrm{V}_{\beta}
\end{array}\right)=2 / 3\left(\begin{array}{ccc}
1 & -0.5 & -0.5 \\
0 & \sqrt{3} / 2 & -\sqrt{3} / 2
\end{array}\right)\left(\begin{array}{c}
\mathrm{V}_{\mathrm{a}} \\
\mathrm{V}_{\mathrm{b}} \\
\mathrm{V}_{\mathrm{c}}
\end{array}\right)
\end{aligned}
$$

The objective of the SV technique is to approximate the line-modulating signal with the eight space vectors $\left(\mathrm{V}_{\mathrm{i}}\right.$, $\mathrm{i}=0$, $2 \ldots 7$ ) available in VSRs. There are eight combinations of switching states available for tracing the voltage command $\left(\mathrm{V}_{\text {ref }}\right)$ in which six states are active voltage space vectors $\left(\mathrm{V}_{\mathrm{i}}, \mathrm{i}=1 \ldots 6\right)$ and two states are zero voltage space vectors $\left(\mathrm{V}_{0}, \mathrm{~V}_{7}\right)$. For example, the PWM sequences for the modulating line-voltage vector located in sector I are shown in fig 4. [17]

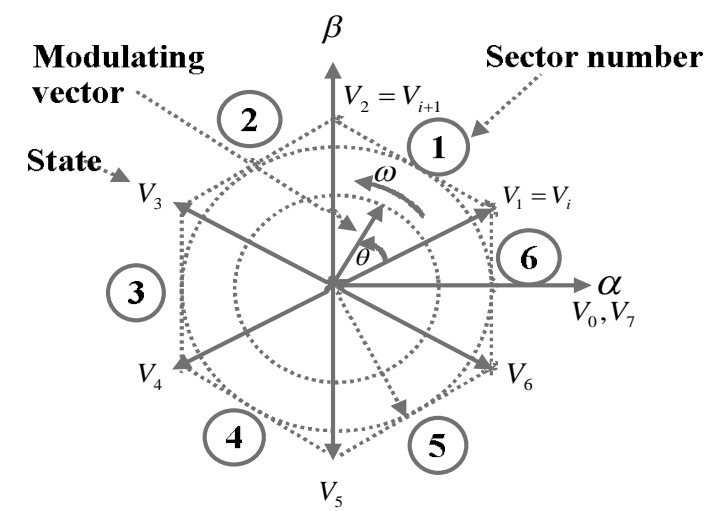

Fig .4 Space vector representation for SVM rectifier

$\mathrm{T}_{1}, \mathrm{~T}_{2}$ and $\mathrm{T}_{\mathrm{z}}$ are corresponding to the time intervals of active states $\mathrm{V}_{1}, \mathrm{~V}_{2}$ and zero state respectively. However, if the modulating signal is laying between the arbitrary vectors $\mathrm{V}_{\mathrm{i}}$ and $\mathrm{V}_{\mathrm{i}+1}$, only the nearest two nonzero vectors $\left(\mathrm{V}_{\mathrm{i}}\right.$ and $\left.\mathrm{V}_{\mathrm{i}+1}\right)$ and one zero space vector $\left(\mathrm{V}_{\mathrm{z}}=\mathrm{V}_{0}\right.$ or $\left.\mathrm{V}_{7}\right)$ should be used. Thus, the maximum load line voltage is maximized and the switching frequency is minimized [18].

(b) Realization of Space Vector PWM [14], [16], [19]-[22]:

The space vector PWM realization is based on the following steps:

Step 1: Determine modulus index $m$ and sector number $S_{n}$

Space vector modulation requires modulus and sector number. Below the mathematical equation are implemented in the diagram.

$\left|\mathrm{V}_{\text {ref }}\right|=\sqrt{\mathrm{V}_{\alpha}{ }^{2}+\mathrm{V}_{\beta}{ }^{2}}, \tan \alpha=\frac{\mathrm{V}_{\beta}}{\mathrm{V}_{\alpha}}$

$\alpha=\omega_{\mathrm{s}} \mathrm{t}=2 \pi \mathrm{f}_{\mathrm{s}} \mathrm{t}$

Where, $\mathrm{fs}=$ fundamental frequency and Modulus index $\mathrm{m}=\mathrm{V}_{\mathrm{ref}} / \mathrm{V}_{\mathrm{d}}$. 


\title{
International Journal of Advanced Research in Electrical, Electronics and Instrumentation Engineering
}

\author{
(An ISO 3297: 2007 Certified Organization)
}

\section{Vol. 3, I ssue 11, November 2014}

The voltage $\mathrm{V}_{\text {ref, }}$, angle $\alpha$ and modulus $\mathrm{m}$ are calculated using the above equations. Table. 1 shows position of rotating vector in a particular sector according to angle $\alpha$.

Table.1 Sector Determination For SVM [17]

\begin{tabular}{|c|c|}
\hline Sector & Angle $(\alpha)$ in degree \\
\hline I & $0 \leq \alpha \leq 60$ \\
\hline II & $60 \leq \alpha \leq 120$ \\
\hline III & $120 \leq \alpha \leq 180$ \\
\hline IV & $180 \leq \alpha \leq 240$ \\
\hline V & $240 \leq \alpha \leq 300$ \\
\hline VI & $300 \leq \alpha \leq 360$ \\
\hline
\end{tabular}

Step 2 : Determine Time Duration $\mathrm{T}_{1}, \mathrm{~T}_{2}, \mathrm{~T}_{0}$

To obtain the required rectifier input space voltage vector, the conduction times of the switches are modulated. $\mathrm{T}_{1}, \mathrm{~T}_{2}$ and $\mathrm{T}_{0}$ for sector $\mathrm{I}\left(0 \leq \alpha \leq 60^{\circ}\right)$ as shown in fig 5 , is calculated by using following equations.

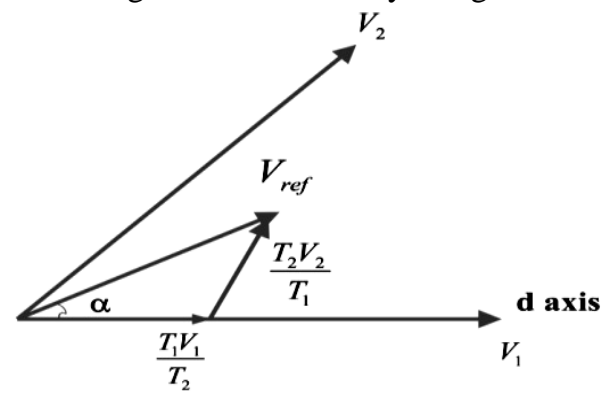

Fig .5 Reference vector as a combination of adjacent vectors at sector 1

$$
\begin{aligned}
& \mathrm{T}_{1}=\mathrm{T}_{\mathrm{z}} \cdot \mathrm{m} \frac{\sin (\pi / 3-\alpha)}{\sin (\pi / 3)} \\
& \mathrm{T}_{2}=\mathrm{T}_{\mathrm{z}} \cdot \mathrm{m} \frac{\sin \alpha}{\sin (\pi / 3)} \\
& \left.\mathrm{T}_{0}=\mathrm{T}_{z}-\left(\mathrm{T}_{1}+\mathrm{T}_{2}\right) \quad \text { (Where } \mathrm{T}_{\mathrm{z}}=1 / \mathrm{f}_{\mathrm{s}} \text { and modulus index } \mathrm{m}=\left|\mathrm{V}_{\text {ref }}\right| /(2 / 3) \cdot \mathrm{V}_{\mathrm{dc}}\right)
\end{aligned}
$$

Thus, the SVM technique utilizes three space vectors $V_{\alpha}, V_{\beta}$ and $V_{o}$ to generate the rectifier input voltage vector in the specified region. For any sector, the switching time duration is calculated by using following equations.

$$
\begin{aligned}
\mathrm{T}_{1} & =\sqrt{ } 3 \mathrm{~T}_{\mathrm{z}} \cdot \mathrm{V}_{\mathrm{ref}} \mid / \mathrm{V}_{\mathrm{dc}}(\sin (\pi / 3-\alpha+(\mathrm{n}-1) \cdot \pi / 3)) \\
& =\sqrt{ } 3 \mathrm{~T}_{\mathrm{z}} \cdot\left|\mathrm{V}_{\mathrm{ref}}\right| / \mathrm{V}_{\mathrm{dc}}(\sin n \pi / 3-\alpha) \\
& =\sqrt{ } 3 \mathrm{~T}_{\mathrm{z}} \cdot \mathrm{V}_{\mathrm{ref}} \mid / \mathrm{V}_{\mathrm{dc}}(\sin n \pi / 3 \cdot \cos \alpha-\cos \mathrm{n} \pi / 3 \cdot \sin \alpha) \\
\mathrm{T}_{2} & =\sqrt{3} \mathrm{~T}_{\mathrm{z}} \cdot \mathrm{V}_{\mathrm{ref}} \mid / \mathrm{V}_{\mathrm{dc}}(\sin (\alpha-(\mathrm{n}-1) \cdot \pi / 3)) \\
& =\sqrt{ } 3 \mathrm{~T}_{\mathrm{z}} \cdot \mathrm{V}_{\mathrm{rd}} \mid / \mathrm{V}_{\mathrm{dc}}(-\cos \alpha \sin (\mathrm{n}-1) \cdot \pi / 3+\sin \alpha \cos (\mathrm{n}-1) \cdot \pi / 3) \\
\mathrm{T}_{0} & =\mathrm{T}_{\mathrm{z}}-\mathrm{T}_{1}-\mathrm{T}_{2},\left(\text { where } \mathrm{n}=1 \text { through } 6 \text { i.e. sector } 1 \text { to } 6,0 \leq \alpha \leq 60^{\circ}\right)
\end{aligned}
$$

Step 3: Determine the switching time of each transistor $\left(S_{1}\right.$ to $\left.S_{6}\right)$

The sequence of switching states to be used should ensure load line voltages that feature quarter-wave symmetry in order to reduce unwanted harmonics in their spectra (even harmonics). Additionally, the zero space vector selection should be done in order to reduce the switching frequency and optimization of switching signal. Whenever start the 


\title{
International Journal of Advanced Research in Electrical, Electronics and Instrumentation Engineering
}

\author{
(An ISO 3297: 2007 Certified Organization)
}

\section{Vol. 3, I ssue 11, November 2014}

new sector form the stationary $\alpha \beta$ coordinate calculate the timing signal. The SVM total time is sum of all time ( $T_{1}, T_{2}$ $\left.\& \mathrm{~T}_{0}\right)$ at instance. This time implement in the particular sector are shown in Table.2.

Table.2 SWITCHING SEQUENCE TABLE FOR SVM [14]

\begin{tabular}{|c|l|l|}
\hline Sector & \multicolumn{1}{|c|}{ Upper Switches $\left(\mathrm{S}_{1} \mathrm{~S}_{3} \mathrm{~S}_{5}\right)$} & \multicolumn{1}{c|}{ Lower Switches $\left(\mathrm{S}_{4} \mathrm{~S}_{6} \mathrm{~S}_{2}\right)$} \\
\hline I & $\mathrm{S}_{1}=\mathrm{T}_{1}+\mathrm{T}_{2}+\mathrm{T}_{0} / 2$ & $\mathrm{~S}_{4}=\mathrm{T}_{0} / 2$ \\
& $\mathrm{~S}_{3}=\mathrm{T}_{2}+\mathrm{T}_{0} / 2$ & $\mathrm{~S}_{6}=\mathrm{T}_{1}+\mathrm{T}_{0} / 2$ \\
& $\mathrm{~S}_{5}=\mathrm{T}_{0} / 2$ & $\mathrm{~S}_{2}=\mathrm{T}_{1}+\mathrm{T}_{2}+\mathrm{T}_{0} / 2$ \\
\hline II & $\mathrm{S}_{1}=\mathrm{T}_{1}+\mathrm{T}_{0} / 2$ & $\mathrm{~S}_{4}=\mathrm{T}_{2}+\mathrm{T}_{0} / 2$ \\
& $\mathrm{~S}_{3}=\mathrm{T}_{1}+\mathrm{T}_{2}+\mathrm{T}_{0} / 2$ & $\mathrm{~S}_{6}=\mathrm{T}_{0} / 2$ \\
& $\mathrm{~S}_{5}=\mathrm{T}_{0} / 2$ & $\mathrm{~S}_{2}=\mathrm{T}_{1}+\mathrm{T}_{2}+\mathrm{T}_{0} / 2$ \\
\hline III & $\mathrm{S}_{1}=\mathrm{T}_{0} / 2$ & $\mathrm{~S}_{4}=\mathrm{T}_{1}+\mathrm{T}_{2}+\mathrm{T}_{0} / 2$ \\
& $\mathrm{~S}_{3}=\mathrm{T}_{1}+\mathrm{T}_{2}+\mathrm{T}_{0} / 2$ & $\mathrm{~S}_{6}=\mathrm{T}_{0} / 2$ \\
& $\mathrm{~S}_{5}=\mathrm{T}_{2}+\mathrm{T}_{0} / 2$ & $\mathrm{~S}_{2}=\mathrm{T}_{1}+\mathrm{T}_{0} / 2$ \\
\hline IV & $\mathrm{S}_{1}=\mathrm{T}_{0} / 2$ & $\mathrm{~S}_{4}=\mathrm{T}_{1}+\mathrm{T}_{2}+\mathrm{T}_{0} / 2$ \\
& $\mathrm{~S}_{3}=\mathrm{T}_{1}+\mathrm{T}_{0} / 2$ & $\mathrm{~S}_{6}=\mathrm{T}_{2}+\mathrm{T}_{0} / 2$ \\
& $\mathrm{~S}_{5}=\mathrm{T}_{1}+\mathrm{T}_{2}+\mathrm{T}_{0} / 2$ & $\mathrm{~S}_{2}=\mathrm{T}_{0} / 2$ \\
\hline $\mathrm{V}$ & $\mathrm{S}_{1}=\mathrm{T}_{2}+\mathrm{T}_{0} / 2$ & $\mathrm{~S}_{4}=\mathrm{T}_{1}+\mathrm{T}_{0} / 2$ \\
& $\mathrm{~S}_{3}=\mathrm{T}_{0} / 2$ & $\mathrm{~S}_{6}=\mathrm{T}_{1}+\mathrm{T}_{2}+\mathrm{T}_{0} / 2$ \\
& $\mathrm{~S}_{5}=\mathrm{T}_{1}+\mathrm{T}_{2}+\mathrm{T}_{0} / 2$ & $\mathrm{~S}_{2}=\mathrm{T}_{0} / 2$ \\
\hline VI & $\mathrm{S}_{1}=\mathrm{T}_{1}+\mathrm{T}_{2}+\mathrm{T}_{0} / 2$ & $\mathrm{~S}_{4}=\mathrm{T}_{0} / 2$ \\
& $\mathrm{~S}_{3}=\mathrm{T}_{0} / 2$ & $\mathrm{~S}_{6}=\mathrm{T}_{1}+\mathrm{T}_{2}+\mathrm{T}_{0} / 2$ \\
& $\mathrm{~S}_{5}=\mathrm{T}_{1}+\mathrm{T}_{0} / 2$ & $\mathrm{~S}_{2}=\mathrm{T}_{2}+\mathrm{T}_{0} / 2$ \\
\hline
\end{tabular}

The SVPWM technique is more popular technique because of the following excellent features:

$>$ It achieves the wide linear modulation range associated with PWM third-harmonic injection automatically,

$>$ It has constant switching frequency with low value because of using null vector,

> It has lower base band harmonics than regular PWM or other sine based modulation methods, or otherwise optimizes harmonics,

$>15 \%$ more output voltage then conventional modulation, i.e. better DC-link utilization,

More efficient use of DC supply voltage,

$>$ Reduced input current THD with power factor improvement,

$>$ Prevent un-necessary switching hence less commutation losses.

Demerit of this is that, it is very complex to implementation.

\section{IV.SIMULATION AND RESULTS}

The simulation has been done using MATLAB/SIMULINK software which it is easy to implement. Various Parameters Used for Simulation Study:

AC input voltage (peak) $=230 \mathrm{~V}$ with Supply frequency $=50 \mathrm{~Hz}$

Rated output power $=7.5 \mathrm{~kW}($ Load resistance $=40 \Omega$, Load inductance $=2 \mathrm{mH})$

$\mathrm{DC}$ reference voltage $=550 \mathrm{~V}$

\section{(a) Sinusoidal PWM}

The output DC link voltage is measured from voltage and current meter block. The DC link and source side voltage and current waveforms of the SPWM for a switching frequency of $10 \mathrm{KHz}$ are shown in fig 6 and fig 7 respectively. 


\section{International Journal of Advanced Research in Electrical, Electronics and Instrumentation Engineering}

(An ISO 3297: 2007 Certified Organization)

Vol. 3, I ssue 11, November 2014
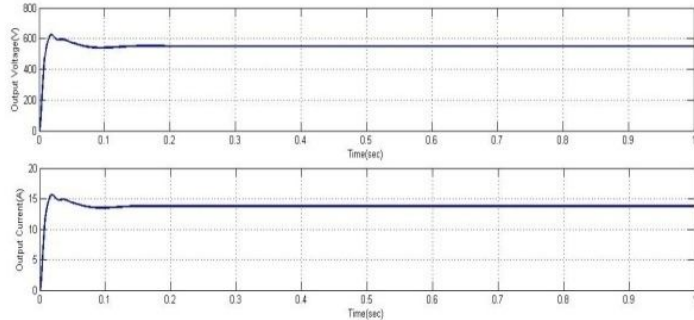

Fig .6 Output voltage (V) \& output current (A) waveform of SPWM at rated load

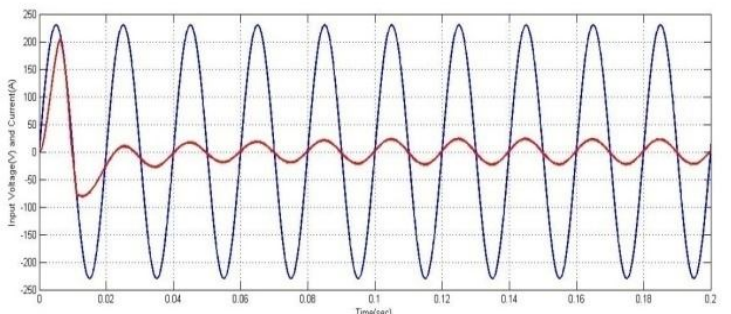

Fig .7 Input voltage (V) \& input current (A) waveform of SPWM at rated load

The input current THD is taken from POWERGUI block of SIMULINK. The FFT analysis of the source current is depicted in fig 8 . The total harmonic distortion of the source current comes out to be $3.68 \%$ so satisfied IEEE standard. The input power factor is calculated from functional block active and reactive power from the simulink model.

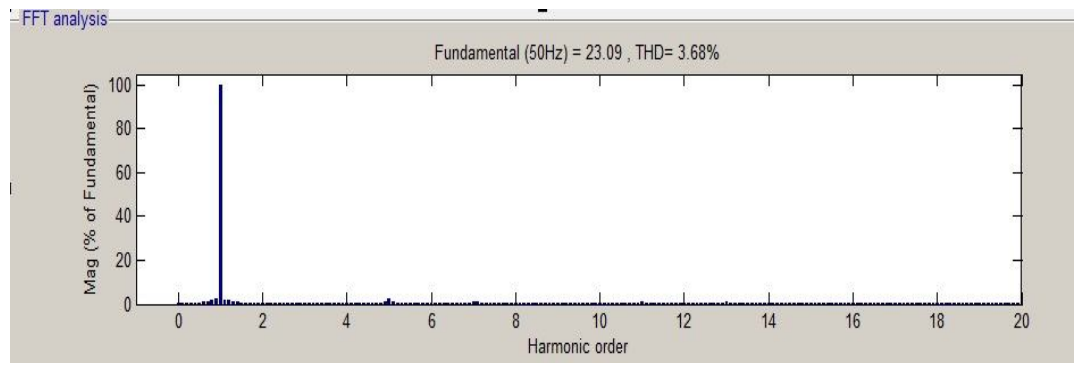

Fig .8 FFT analysis of input current (A) of SPWM at rated load

(b) Space Vector PWM

The output DC link voltage is measured from voltage and current meter block. The DC link and source side voltage and current waveforms of the SVPWM for a switching frequency of $10 \mathrm{KHz}$ are shown in fig 9 and fig 10 respectively.
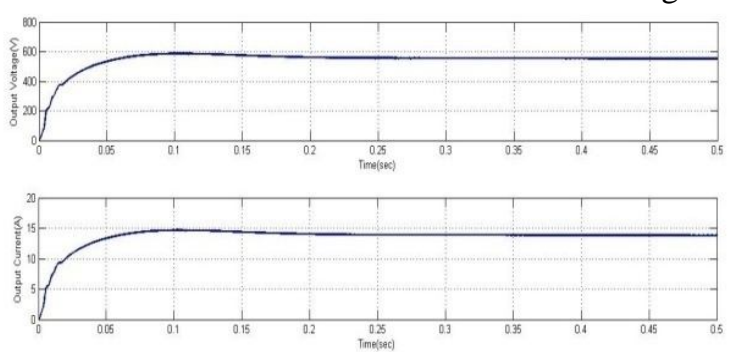

Fig 9 Output voltage (V) \& output current (A) waveform of SVPWM at rated load

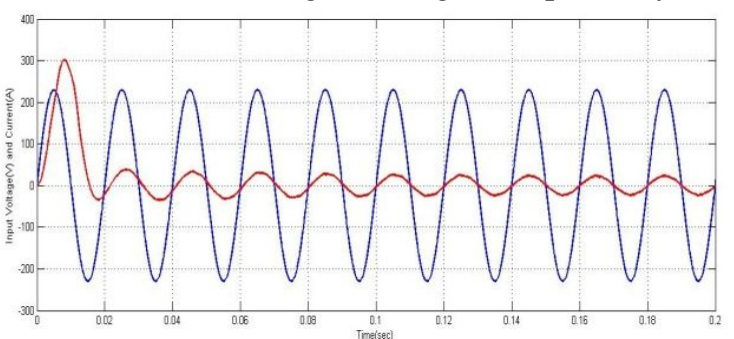

Fig .10 Input voltage (V) \& input current (A) waveform of SVPWM at rated load

The input current THD is taken from POWERGUI block of SIMULINK. The FFT analysis of the source current is depicted in fig 11 . The THD of the source current comes out to be $2.68 \%$ so satisfied IEEE standard. So, at the $10 \mathrm{KHz}$ frequency very less harmonic continue in input current. The input power factor is calculated from functional block active and reactive power as shown in simulink model. 


\section{International Journal of Advanced Research in Electrical, Electronics and Instrumentation Engineering}

(An ISO 3297: 2007 Certified Organization)

Vol. 3, I ssue 10, October 2014

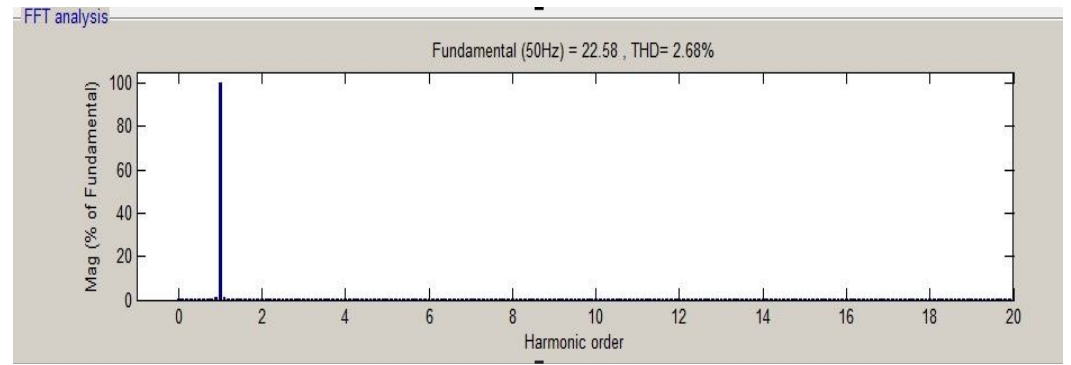

Fig .11 FFT Analysis of input current (A) of SVPWM rectifier at rated load

\section{V.CONCLUSION}

The proposed work presents the harmonics analysis of SPWM and SVPWM based three-phase AC to DC PWM converters. Both techniques are simulated using MATLAB/SIMULUINK software and their performance is compared in terms of input power factor and input current THD value at rated load condition for harmonics analysis. From the Simulation, at rated load condition, the power factor obtained for SPWM is 0.9972 and unity power factor for SVPWM. Harmonic analysis for input current THD is done by using FFT tool at rated load condition. The input current THD obtained for SPWM is $3.68 \%$ and $2.68 \%$ for SVPWM. From these simulation results it is concluded that unity power factor operation with minimum THD is obtained by SVPWM technique so that SVPWM gives better performance compared to SPWM. The SVPWM technique is definitely an improvement over the SPWM technique as the THD of the source current is reduced.

\section{REFERENCES}

[1] Kataoka, T., Mizumachi, K., and Miyairi, S., "A Pulse-width Controlled AC-to-DC Converter to Improve Power Factor and Waveform of AC Line Current”, IEEE Transactions on Industry Applications, Vol. IA-15, Issue No. 6, pp.670-675, 1979.

[2] Dixon, J. W., and Ooi, B. T., "Indirect Current Control of a Unity Power Factor Sinusoidal Current Boost type Three-phase Rectifier", IEEE Transactions on Industrial Electronics, Vol. 35, Issue No. 4, pp.508-515, 1988.

[3] Xue, M., and He, M., "Control of Unity Power Factor PWM Rectifier", Scientific research, Energy and Power Engineering (EPE), Vol. 5, Issue No. 4B, pp.121-124, 2013.

[4] Srivastava, S., and Kumar, S., "Comparative Analysis of Improved Quality Three Phase AC/DC Boost Converters, using SIMULINK", International Journal of Emerging Technology and Advanced Engineering, Vol. 2, Issue No. 9, pp.427-432, 2012.

[5] Bhat, A. H., and Agarwal, P., "A Comparative Evaluation of Three-Phase High Power Factor Boost Converters for Power Quality Improvement”, IEEE, International Conference on Industrial Technology (ICIT), pp.546-551, 2006.

[6] Zhongjiu, Z., Guofeng, L., and Ninghui, W., "Research on Control Strategy of Three-phase High Power Factor PWM Rectifier", International Journal of Digital Content Technology and its Applications, vol. 5, Issue No. 8, pp.365-373, 2011.

[7] Balamurugan, R., and Dr. Gurusamy, G., "Harmonic Optimization by Single Phase Improved Power Quality AC-DC Power Factor Corrected Converters", International Journal of Computer Applications (0975 - 8887), Vol. 1, Issue No. 5, pp.33-40, 2010.

[8] Rajnikanth and Dr. Nagapadma, R., "Simulation of AC/DC/AC Converter for Closed Loop Operation of Three-phase Induction Motor", International Journal of Advanced Research in Computer and Communication Engineering, Vol. 3, Issue No. 6, pp.7074-7079, 2014.

[9] Bhattacharya, S., Deb, P., Dr. Biswas, S. K., and DR. Chowdhury, S. K., "A Comprehensive Study of Modulation Strategies for Three Phase Low Cost PWM Converter", International Journal of Engineering Science and Technology (IJEST), Vol. 3, Issue No. 7, pp.5475-5480, 2011.

[10] Vasudevamurthy, S., and Swetha, "Simulation and Comparison of Space Vector Pulse Width Modulation for Three Phase Voltage Source Inverter", International Journal of Engineering Research \& Technology (IJERT), Vol. 2, Issue No. 5, pp.1691-1698, 2013.

[11] Ahmed, W., and Ali, S. M. U., "Comparative study of SVPWM (Space Vector Pulse Width Modulation) \& SPWM (Sinusoidal Pulse Width Modulation) Based Three-phase Voltage Source Inverters for Variable Speed Drive", IOP Conf. Series: Materials Science and Engineering (ICSICCST), pp.1-8, 2013

[12] Mounika, K., and Babu, B. K., "Sinusoidal and Space Vector Pulse Width Modulation for Inverter", International Journal of Engineering Trends and Technology (IJETT), Vol. 4, Issue No. 4, pp.1012-1017, 2013.

[13] Kumar, K. V., Michael, P. A., John, J. P., and Dr. Kumar, S. S., "Simulation and Comparison of SPWM and SVPWM Control for Three Phase Inverter", ARPN Journal of Engineering and Applied Sciences, Vol. 5, Issue No. 7, pp.61-74, 2010.

[14] Rathnakumar, D., Perumal, J. L., and Srinivasan, T., “A New Software Implementation of Space Vector PWM”, Southeast Con, Proceedings IEEE, pp.131-136, 2005.

[15] Singh, S. P., Narasimharaju, B. L., and Kumar, N. R., "Performance analysis of AC-DC power converter using PWM techniques", 2nd International Conference on Advances in Energy Engineering (ICAEE 2011), Science Direct, Energy Procedia, Vol. 14, pp.880-886, 2012.

[16] Sasi, D., and Kuruvilla P. J., "Modelling and Simulation of SVPWM Inverter Fed Permanent Magnet Brushless DC Motor Drive", International Journal of Advanced Research in Electrical, Electronics and Instrumentation Engineering (IJAREEIE), Vol. 2, Issue No. 5, pp.19471955, 2013.

[17] Hao, M., Yunping, L., and Huiming, C., "A Simplified Algorithm for Space Vector Modulation of Three-phase Voltage Source PWM Rectifier”, IEEE, 35th Annual Power Electronics Specialists Conference (PESC 04), Vol. 5, pp.3665-3670, 2004. 


\title{
International Journal of Advanced Research in Electrical, Electronics and Instrumentation Engineering
}

\author{
(An ISO 3297: 2007 Certified Organization)
}

\section{Vol. 3, I ssue 10, October 2014}

[18] Zhou, K., and Wang, D., "Relationship between Space-Vector Modulation and Three-Phase Carrier-Based PWM: A Comprehensive Analysis", IEEE Transactions on Industrial Electronics, Vol. 49, Issue No. 1, pp.186-196, 2002.

[19] Bilhan, A. K., and Akbal, E., "Modelling and Simulation of Two-level Space Vector PWM Inverter using Photovoltaic Cells as DC Source", International Journal of Electronics Mechanical and Mechatronics Engineering, Vol.2, Issue No. 4, pp.311-317.

[20] Hendawi, E., Khater, F., and Shaltout, A., "Analysis, Simulation and Implementation of Space Vector Pulse Width Modulation Inverter", Proceedings of the 9th WSEAS International Conference on Applications of Electrical Engineering (AEE'10), pp.124-131, 2010.

[21] Xu, W., Kaizheng, H., Shijie, Y., and Bin, X., "Simulation of Three-phase Voltage Source PWM Rectifier Based on The Space Vector Modulation", IEEE, Chinese Control and Decision Conference (CCDC), pp.1881-1884, 2008.

[22] Nagaiah, M., and Rakesh, V. G., "A Novel Space Vector Modulation (SVM) Controlled Inverter for Adjustable Speed Drive Applications", International Journal of Engineering Inventions, Vol. 3, Issue No. 1, pp.58-66, 2013. 